
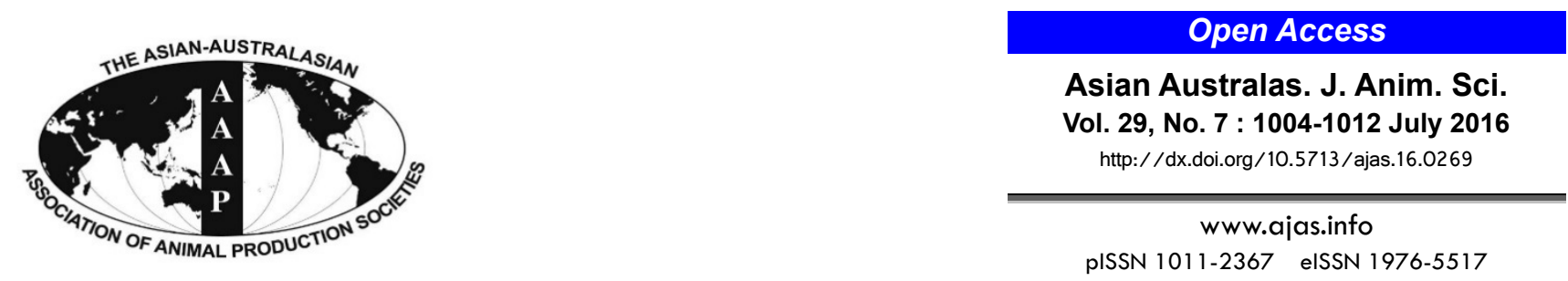

\title{
Effects of Dietary Energy Levels on the Physiological Parameters and Reproductive Performance of Gestating Gilts
}

\author{
S. S. Jin, S. W. Jung, J. C. Jang, W. L. Chung, J. H. Jeong, and Y. Y. Kim* \\ School of Agricultural Biotechnology, and Research Institute for Agriculture and Life Science, \\ Seoul National University, Seoul 151-921, Korea
}

\begin{abstract}
This experiment was conducted to investigate the effects of dietary energy levels on the physiological parameters and reproductive performance of gestating first parity sows. A total of $52 \mathrm{~F} 1$ gilts (Yorkshire $\times$ Landrace) were allocated to 4 dietary treatments using a completely randomized design. Each treatment contained diets with 3,100, 3,200, 3,300, or 3,400 kcal of metabolizable energy (ME)/kg, and the daily energy intake of the gestating gilts in each treatment were 6,200, 6,400,6,600, and 6,800 $\mathrm{kcal}$ of ME, respectively. During gestation, the body weight $(\mathrm{p}=0.04)$ and weight gain $(\mathrm{p}=0.01)$ of gilts linearly increased with increasing dietary energy levels. Backfat thickness was not affected at d110 of gestation by dietary treatments, but increased linearly ( $p$ $=0.05$ ) from breeding to d 110 of gestation. There were no significant differences on the litter size or litter birth weight. During lactation, the voluntary feed intake of sows tended to decrease when the dietary energy levels increased $(p=0.08)$. No difference was observed in backfat thickness of the sows within treatments; increasing energy levels linearly decreased the body weight of sows $(p<0.05)$ at $d 21$ of lactation and body weight gain during lactation $(p<0.01)$. No significant differences were observed in the chemical compositions of colostrum and milk. Therefore, these results indicated that high-energy diets influenced the bodyweight and backfat thickness of sows during gestation and lactation. NRC (2012) suggested that the energy requirement of the gestation gilt should be between 6,678 and $7,932 \mathrm{kcal}$ of $\mathrm{ME} / \mathrm{d}$. Similarly, our results suggested that 3,100 kcal of ME/kg is not enough to maintain the reproductive performance for gilts during gestation with $2 \mathrm{~kg}$ feed daily. Gilts in the treatment 3,400 kcal of ME/kg have a higher weaning number of piglets, but bodyweight and backfat loss were higher than other treatments during lactation. But bodyweight and backfat loss were higher than other treatments during lactation. Consequently, an adequate energy requirement of gestating gilts is 6,400 kcal of ME/d. (Key Words: Energy Level, Gilts, Body Weight, Backfat Thickness, Reproductive Performance)
\end{abstract}

\section{INTRODUCTION}

Sow productivity has developed extensively in recent decades due to the improvement of the high genetic potential in modern sows. According to the Canadian Centre for Swine Improvement (2015) the average litter size is 14.00 in modern sows, mainly due to the increased sow productivity. Efforts to meet the nutrient requirements of high-producing sows have been undertaken by supplementing nutrients to support both the normal reproductive cycle and body maturation (Boyd et al., 2000).

\footnotetext{
* Corresponding Author: Y. Y. Kim. Tel: +82-2-878-5838, Fax: +82-2-878-5839, E-mail: yooykim@snu.ac.kr Submitted Apr. 6, 2016; Revised Apr. 27, 2016; Accepted May 25, 2016
}

Primiparous sows are particularly sensitive to adequate energy during gestation, as they are still growing and utilizing ingested nutrients to support body maturation, growth of the fetus and body maintenance (Jang et al., 2014).

However, prior research in energy supplementation in the diet is still controversial. Almeida (2000) reported that high dietary energy levels during the ovulation period can increase the ovulation rate and promote progesterone secretion to increase fetal survival. In addition, Kongsted (2005) demonstrated that higher energy intake in gestation period may reduce the risk of being culled due to pregnancy failure because of insufficient body weight (BW) gain and backfat deposition. Recently, NRC (2012) suggested that higher energy intake is good for the development and 
growth of the fetus, corresponding tissues (placenta, uterus, and mammary tissue) and deposition of maternal lipids and proteins. The energy requirement of gestating gilts and sows should be between 6,678 and $8,182 \mathrm{kcal}$ of metabolizable energy $(\mathrm{ME}) / \mathrm{d}$, which is $1,650 \mathrm{kcal}$ higher than previous recommendations (NRC, 1998). However, more research is needed to understand the precise energy requirements of gestating gilts.

Therefore, the objective of the current study is to determine the optimal dietary energy level for reproductive performance in high-producing modern sows.

\section{MATERIALS AND METHODS}

\section{Animal preparation}

A total of 52 gilts (Large White $\times$ Landrace) that were, on average, $150 \mathrm{~d}$ old and weighed approximately $85 \mathrm{~kg}$ were selected and housed in an $11 \times 14 \mathrm{~m}$ barn. Sows were provided feed and water ad libitum until reaching $120 \mathrm{~kg}$ of BW and then moved to individual gestation stall cages with concrete slatted floors $(0.64 \times 2.40 \mathrm{~m})$. Diets were fed individually, twice daily with $800 \mathrm{~g}$ each time for an ADG of $750 \mathrm{~g} / \mathrm{d}$. Gilts were mated at an average BW of $136 \mathrm{~kg}$ after three or four estrus cycles. Semen (Darby AI center, Chung Ju, Korea) collected from 88 boars (Duroc) in the same batch was provided for the artificial insemination (AI) of gilts.

\section{Experimental design and animal management}

A total of 52 crossbred gilts (large White $\times$ Landrace) averaging 240 days of age with a BW of $135.82 \pm 0.85 \mathrm{~kg}$ were allotted to 4 dietary treatments by BW and backfat thickness (BFT) in a completely random design with 13 replicates. Experimental diets for gestating gilts were formulated to contain $13.08 \%$ crude protein, $0.86 \%$ lysine, $0.90 \%$ calcium and $0.70 \%$ phosphorus, with energy contents of $3,100,3,200,3,300$, or $3,400 \mathrm{kcal}$ of $\mathrm{ME} / \mathrm{kg}$, respectively. Feed was provided at $2.0 \mathrm{~kg} / \mathrm{d}$ for all treatments. Lactating diets contained 3,265 kcal ME/kg, $17.07 \% \mathrm{CP}, 1.26 \%$ lysine, $0.90 \%$ calcium, and $0.70 \%$ phosphorus, respectively (Table 1). All other nutrients were formulated to meet or exceed the NRC requirements (2012). Gilts were housed in temperature-controlled rooms and placed in an individual crate $(2.4 \times 0.65 \mathrm{~m})$ with a concrete floor until d 110 of gestation. After d 110 of gestation, pregnant gilts were washed and moved into farrowing crates $(2.4 \times 1.8 \mathrm{~m})$. During the lactation period, all sows were fed the same commercial lactation diet. After farrowing, the lactation diet was increased gradually from $1.0 \mathrm{~kg} / \mathrm{d}$ until 5 $\mathrm{d}$ postpartum and then provided ad libitum during the lactation period. Weaning was performed at approximately $21 \mathrm{~d}$.
Table 1. Formula and chemical composition of gestating and lactating diets $(\%)$

\begin{tabular}{|c|c|c|c|c|c|}
\hline \multirow{2}{*}{ Items } & \multicolumn{4}{|c|}{ Gestating diets (ME, $\mathrm{kcal} / \mathrm{kg}$ ) } & \multirow{2}{*}{$\begin{array}{c}\text { Lactating } \\
\text { diets }\end{array}$} \\
\hline & 3,100 & 3,200 & 3,300 & 3,400 & \\
\hline \multicolumn{6}{|l|}{ Ingredients $(\%)$} \\
\hline Corn & 56.59 & 54.56 & 52.53 & 50.50 & 67.51 \\
\hline $\begin{array}{c}\text { Soybean meal } \\
(46 \% \mathrm{CP})\end{array}$ & 10.09 & 10.44 & 10.78 & 11.12 & 25.57 \\
\hline Sugar molasse & & & & & 1.00 \\
\hline Tallow & 0.45 & 2.13 & 3.82 & 5.50 & - \\
\hline Soy oil & - & - & - & - & 1.30 \\
\hline Barley & 25.00 & 25.00 & 25.00 & 25.00 & - \\
\hline Rapeseed meal & 3.60 & 3.60 & 3.60 & 3.60 & - \\
\hline L-lysine $\cdot \mathrm{Hcl}$ & 0.41 & 0.40 & 0.40 & 0.40 & 0.60 \\
\hline DL-methionine & 0.04 & 0.04 & 0.04 & 0.04 & - \\
\hline Dicalciumphosphate & 2.36 & 2.39 & 2.41 & 2.43 & 2.30 \\
\hline Limestone & 0.86 & 0.84 & 0.82 & 0.81 & 0.85 \\
\hline Vit. Mix ${ }^{1}$ & 0.10 & 0.10 & 0.10 & 0.10 & 0.20 \\
\hline Min. Mix $^{2}$ & 0.10 & 0.10 & 0.10 & 0.10 & 0.10 \\
\hline Salt & 0.25 & 0.25 & 0.25 & 0.25 & 0.42 \\
\hline Choline chloride-50 & 0.15 & 0.15 & 0.15 & 0.15 & 0.15 \\
\hline \multicolumn{6}{|c|}{ Chemical compositions ${ }^{3}(\%)$} \\
\hline $\mathrm{ME}(\mathrm{kcal} / \mathrm{kg})$ & 3,100 & 3,200 & 3,300 & 3,400 & 3,265 \\
\hline $\mathrm{CP}$ & 13.08 & 13.08 & 13.08 & 13.08 & 17.07 \\
\hline Lys & 0.86 & 0.86 & 0.86 & 0.86 & 1.26 \\
\hline Met & 0.23 & 0.23 & 0.23 & 0.23 & 0.25 \\
\hline $\mathrm{Ca}$ & 0.90 & 0.90 & 0.90 & 0.90 & 0.90 \\
\hline Total P & 0.70 & 0.70 & 0.70 & 0.70 & 0.70 \\
\hline Available P & 0.42 & 0.42 & 0.42 & 0.42 & 0.41 \\
\hline
\end{tabular}

ME, metabolizable energy; $\mathrm{CP}$, crude protein.

${ }^{1}$ Provided per kg of diet: Vit. A, 10,000 IU; Vit. D 3 , 1,500 IU; Vit. E, 35 IU; Vit. $\mathrm{K}_{3}, 3 \mathrm{mg}$; Vit. $\mathrm{B}_{2}, 4 \mathrm{mg}$; Vit. $\mathrm{B}_{6}, 3 \mathrm{mg}$; Vit. $\mathrm{B}_{12}, 15 \mu \mathrm{g}$; pantothenic acid, $10 \mathrm{mg}$; biotin, $50 \mu \mathrm{g}$; niacin, $20 \mathrm{mg}$; folic acid $500 \mu \mathrm{g}$.

${ }^{2}$ Provided per kg of diet: Fe, $75 \mathrm{mg}$; Mn, $20 \mathrm{mg}$; Zn, $30 \mathrm{mg}$; Cu, $55 \mathrm{mg}$; Se $100 \mu \mathrm{g} ; \mathrm{I}, 250 \mu \mathrm{g}$; Co, $250 \mu \mathrm{g}$.

${ }^{3}$ Calculated value.

\section{Measurements and analysis}

The BW and BFT at the P2 position of sows were measured. Body length was measured from the center of both ears to the tail with a measuring tape. Blood samples were collected at breeding, 110 days of gestation, $24 \mathrm{~h}$ post farrowing, and 21 days of lactation. The number of total born, piglets born alive, still born, and mummified fetuses as well as the piglet BW were recorded. The fat and protein mass of primiparous sows were calculated using the equations of Dourmad et al. (1997).

EBW $(\mathrm{kg})=$ sow empty live weight estimated from the live weight $\left(=0.905 \times \mathrm{BW}^{1.013}\right)$

$$
\text { Fat } \begin{aligned}
(\mathrm{kg})= & -26.4+0.221 \times(\mathrm{EBW}, \mathrm{kg}) \\
& +1.331 \times(\text { Backfat }, \mathrm{mm})
\end{aligned}
$$




$$
\begin{aligned}
\text { Protein }(\mathrm{kg})= & 2.28+0.178 \times(\mathrm{EBW}, \mathrm{kg}) \\
+ & 0.333 \times(\text { Backfat }, \mathrm{mm})
\end{aligned}
$$

Blood samples were collected from the jugular vein of sows and piglets with heparinized tubes and centrifuged immediately at $3,000 \mathrm{rpm}$ at $4^{\circ} \mathrm{C}$, and then, plasma was separated and stored at $-20^{\circ} \mathrm{C}$ until later analysis. Colostrum and milk were collected from the first and second teats at $24 \mathrm{~h}$ and $21 \mathrm{~d}$ postpartum after an intravascular injection of 5 IU oxytocin (Komi oxytocin inj. Komipharm International Co., Ltd., Siheung, Korea) in the ear. All samples were stored at $-20^{\circ} \mathrm{C}$ until analysis. Proximate analysis of colostrum and milk samples was conducted using a Milkoscan FT 120 (FOSS Electric, Sungnam, Korea). Plasma free fatty acid (FFA) concentrations were determined according to the colorimetric Acyl-CoA synthetase Acyl-CoA oxidase (ACSACOD) method (Shimizu et al., 1979) using a commercial kit (Wako FFA c Kit; Wako chemical, Osaka, Japan). The serum glucose and blood urea nitrogen (BUN) concentrations were analyzed ug a kinetic UV assay (Glucose Hexokinase Kit; UREA/BUN Kit, Roche, Mannheim, Germany). The fatty acid content in colostrum was analyzed on a Agilent 7890 Gas Liquid Chromatograph (Agilent Technologies, Palo Alto, CA, USA) equipped with a flame ionization detector and a SP-2560 (i.d. $100 \mathrm{~m} \times 0.25$ $\mathrm{mm} \times 0.20 \mu \mathrm{m})$ film column. Nitrogen was used as carrier gas, injector core temperature was $250^{\circ} \mathrm{C}$, detector temperature was $260^{\circ} \mathrm{C}$ and column temperature was programmed to begin at $170^{\circ} \mathrm{C}$, then increase to $250^{\circ} \mathrm{C}$ and remain at $240^{\circ} \mathrm{C}$ for $40 \mathrm{~min}$. Chromatography was calibrated with a mixture of 37 different fatty acids (FAME 37; Supelco Inc., Bellefonte, PA, USA), this standard contained fatty acids ranging from $\mathrm{C} 4: 0$ to $\mathrm{C} 24: 1 \mathrm{n} 9$, and samples were added $250 \mu \mathrm{L}$ of internal standard spike solution (Pentadecanoic acid; Sigma, Saint Louis, MO, USA) by the method of AOAC (1990). Colostrum samples were centrifuged at $105,000 \times \mathrm{g}$ at $4^{\circ} \mathrm{C}$ for 1 hour and the supernatant was separated and kept frozen until colostrum immunoglobulin $\mathrm{G}$ ( $\mathrm{IgG}$ ) and immunoglobulin A ( $\mathrm{IgA}$ ) analysis. Colostrum $\operatorname{IgG}$ and $\operatorname{IgA}$ concentrations were determined using ELISA according to the manufacture's protocols (Elisa Starter Accessory Package, pig IgG ELISA Quantification Kit, pig IgA ELISA Quantification kit; Bethyl, Montgomery, TX, USA).

\section{Statistical analysis}

Data were analyzed by analysis of variance with a completely randomized design using the general linear model procedure implemented in SAS (SAS Institute, 2004). The least squares means were calculated for each independent variable. Orthogonal polynomial contrasts were used to determine the linear and quadratic effects by increasing the dietary energy levels in gestation for all measurements of sows and piglets. Individual sows and their litters were used as the experimental unit. The alpha level used for the determination of significance for all analyses was 0.05 and for the determination of trends was $\mathrm{p}>0.05$ and $\mathrm{p}<0.10$.

\section{RESULTS}

The effects of the energy level on BW and BFT are presented in Table 2. Body weight and BW gain in gestation increased as the dietary energy level increased (linear response, $\mathrm{p}<0.05$ ). Back fat thickness was not affected by dietary treatments during the gestation period, but back fat gain from breeding to $110 \mathrm{~d}$ of gestation increased linearly $(p<0.05)$ as the dietary energy level increased. Body length was not affected by dietary treatments. During the lactation period, the BW and BW gain of sows decreased as energy levels increased (linear response, $\mathrm{p}<0.05$ ), but back fat thickness was not affected by treatments. Consequently, the BW change of gilts from mating to 3 weeks of lactation tended to decrease as energy levels increased (linear response, $\mathrm{p}=0.06$ ). During the lactation period, the voluntary feed intake of sows tended to decrease (linear response, $\mathrm{p}=0.08$ ) when dietary energy levels increased (Table 2). The weaning to estrus interval (WEI) was not significantly affected by treatments, but the culling rates of sows were highest in the $3,100 \mathrm{kcal} / \mathrm{kg}$ ME treatment (Table $2)$. The estimated protein and fat masses of gilts were calculated based on the BW and BFT (Dourmad et al., 1997). The protein mass and fat mass increased as energy levels increased (linear response, $\mathrm{p}<0.01$, and $\mathrm{p}<0.05$, respectively) during the gestation period (Table 3 ). During the lactation period, the protein mass and fat mass decreased (linear and quadratic response, $\mathrm{p}<0.01$, and $\mathrm{p}<0.05$, respectively), while the dietary energy level increased (Table 3). There were no significant differences in the total number of pigs born per litter or litter birth weight (Table 4). There were also no significant differences in the fat, protein, lactose, or solid-not-fat (SNF) content of colostrum and milk (Table 5). There was no significant difference in the fatty acid content of colostrum due to dietary energy levels (Table 6). The BUN concentration in the serum of gilts tended to increase with dietary energy level at d 110 of gestation and $24 \mathrm{~h}$ postpartum (linear response, $\mathrm{p}=0.06$, and $\mathrm{p}=0.07$, respectively) (Table 7). The glucose concentrations tended to increase with dietary energy level (linear response, $\mathrm{p}=0.07$ ) at $24 \mathrm{~h}$ postpartum, but the FFA concentration was not affected (Table 7). There were no significant differences in the concentration of $\mathrm{IgG}$ or IgA in colostrum (Table 8).

\section{DISCUSSION}

In the current study, increasing energy intake led to a 
Table 2. Effects of the dietary energy levels on the body weight, back-fat, body length, feed intake and WEI of primiparous gestating and lactating sows

\begin{tabular}{|c|c|c|c|c|c|c|c|}
\hline \multirow{2}{*}{ Criteria } & \multicolumn{4}{|c|}{ Treatment } & \multirow{2}{*}{ SEM } & \multicolumn{2}{|c|}{ p-value } \\
\hline & $3,100^{1}$ & 3,200 & 3,300 & 3,400 & & Linear & Quadratic \\
\hline \multicolumn{8}{|l|}{ Gestation } \\
\hline No. of sows & 13 & 13 & 13 & 13 & & & \\
\hline \multicolumn{8}{|l|}{ Body weight (kg) } \\
\hline Breeding (d) & 136.00 & 135.95 & 135.68 & 135.35 & 0.85 & 0.64 & 0.96 \\
\hline D 110 & 178.50 & 182.18 & 182.59 & 185.81 & 1.42 & 0.04 & 0.74 \\
\hline Breeding-110 d (change) & $42.50^{\mathrm{b}}$ & $46.22^{\mathrm{ab}}$ & $46.91^{\mathrm{ab}}$ & $50.46^{\mathrm{a}}$ & 1.08 & 0.01 & 0.69 \\
\hline \multicolumn{8}{|l|}{ Backfat thickness (mm) } \\
\hline Breeding (d) & 19.32 & 19.18 & 18.55 & 19.08 & 0.56 & 0.90 & 0.55 \\
\hline D 110 & 20.72 & 21.27 & 20.45 & 23.08 & 0.70 & 0.22 & 0.26 \\
\hline Breeding-110 d (change) & 1.40 & 2.09 & 1.91 & 4.00 & 0.43 & 0.05 & 0.32 \\
\hline \multicolumn{8}{|l|}{ Body length (cm) } \\
\hline Breeding (d) & 113.90 & 115.00 & 114.17 & 113.62 & 0.56 & 0.31 & 0.40 \\
\hline D 110 & 121.55 & 122.18 & 120.96 & 121.96 & 0.58 & 0.83 & 0.80 \\
\hline Breeding-110 d (change) & 7.65 & 7.18 & 6.79 & 8.35 & 0.53 & 0.51 & 0.33 \\
\hline \multicolumn{8}{|l|}{ Lactation } \\
\hline \multicolumn{8}{|l|}{ Body weight (kg) } \\
\hline $24 \mathrm{~h}$ post farrowing & 164.72 & 165.68 & 162.08 & 169.00 & 1.28 & 0.53 & 0.26 \\
\hline Weaning & $174.11^{\mathrm{a}}$ & $173.45^{\mathrm{a}}$ & $168.88^{b}$ & $167.27^{\mathrm{b}}$ & 1.55 & 0.03 & 0.70 \\
\hline Post farrowing-21 d (gain) & $9.39^{\mathrm{a}}$ & $7.77^{\mathrm{a}}$ & $6.79^{\mathrm{a}}$ & $-1.73^{\mathrm{b}}$ & 1.24 & 0.01 & 0.10 \\
\hline Breeding-21 d postpartum (gain) & 39.72 & 37.50 & 33.79 & 31.92 & 1.31 & 0.06 & 0.90 \\
\hline \multicolumn{8}{|l|}{ Backfat thickness (mm) } \\
\hline $24 \mathrm{~h}$ post farrowing & 21.06 & 20.32 & 20.83 & 21.77 & 0.64 & 0.57 & 0.49 \\
\hline Weaning & 18.94 & 18.73 & 19.37 & 18.27 & 0.57 & 0.87 & 0.77 \\
\hline 0-21 d (gain) & -2.12 & -1.59 & -1.46 & -3.5 & 0.35 & 0.19 & 0.08 \\
\hline Breeding $-21 \mathrm{~d}$ (gain) & 0.56 & -0.45 & 0.66 & -0.81 & 0.47 & 0.91 & 0.72 \\
\hline Average feed intake $(\mathrm{kg} / \mathrm{d})$ & 5.99 & 5.77 & 5.79 & 5.32 & 0.11 & 0.08 & 0.16 \\
\hline Weaning to estrus interval & 5.29 & 5.27 & 5.17 & 5.67 & 0.18 & 0.99 & 0.20 \\
\hline Culling rate $(\%)$ & 38 & 7 & 7 & 15 & - & - & - \\
\hline
\end{tabular}

WEI, weaning to estrus interval; SEM, standard error of mean; ME, metabolizable energy.

${ }^{1}$ Energy intake ME kcal $/ \mathrm{kg}$.

${ }^{\mathrm{a}, \mathrm{b}}$ Means with different superscripts indicate significant differences $(\mathrm{p}<0.05)$.

higher BW and BW gain from 42.5 to $50.46 \mathrm{~kg}$, which agreed with the results of Noblet et al. (1990), who observed an increased BW of gilts during gestation with higher energy intake. This observation may be attributed to the higher BFT due to the high dietary energy during gestation (Long et al., 2010). In the present study, although gilts consumed an equal amount of amino acids, fat tissue and protein tissue was increased during gestation, but decreased during lactation, which implies that the energy supply is important to maintain adequate BW and BFT for subsequent reproductive cycles. These results are in agreement with previous studies, which demonstrated that increased feed intake during gestation increased sow weight loss during subsequent lactation (Piao et al., 2010). Moreover, Long (2010) demonstrated that providing highenergy feed during gestation increased BW and BFT loss in the lactation period. The BFT loss during lactation was observed in the highest energy level treatment, which may be attributed to reduced feed intake during lactation due to higher dietary energy levels in gestation.

In this study, WEI was not affected by treatments and the culling rate was highest in the $3,100 \mathrm{kcal} / \mathrm{kg} \mathrm{ME}$ treatments. Previous studies indicated that increasing body fatness at farrowing is likely to decrease feed intake during lactation (Xue et al., 1997). Low feed intake during lactation could result in higher BW loss and subsequently lead to several common reproductive problems, such as an increased WEI interval (Baidoo et al., 1992), increased anestrus incidence after weaning, and decreased conception rate (Kirkwood and Thacker, 1988). Although feed intake decreased and BW loss increased during lactation with increasing energy levels during gestation, high dietary energy levels did not increase the culling rate in the first parity. However, treatment with $3,100 \mathrm{kcal}$ of $\mathrm{ME} / \mathrm{kg}$ showed the highest culling rate (38\%) due to pregnancy failure and post-weaning anestrus, which suggests that low 
Table 3. Effects of the dietary energy level on the estimated protein, fat mass and its gain of primiparous gestating and lactating sows

\begin{tabular}{|c|c|c|c|c|c|c|c|}
\hline \multirow{2}{*}{ Criteria } & \multicolumn{4}{|c|}{ Treatment } & \multirow{2}{*}{ SEM } & \multicolumn{2}{|c|}{$\mathrm{p}$-value } \\
\hline & $3,100^{1}$ & 3,200 & 3,300 & 3,400 & & Linear & Quadratic \\
\hline \multicolumn{8}{|c|}{ Estimated protein mass ${ }^{2}$ in gestation $(\mathrm{kg})$} \\
\hline Breeding (d) & 31.57 & 31.90 & 31.59 & 31.76 & 0.27 & 0.93 & 0.95 \\
\hline d 110 & $39.80^{\mathrm{b}}$ & $40.50^{\mathrm{ab}}$ & $40.54^{\mathrm{ab}}$ & $41.72^{\mathrm{a}}$ & 0.39 & 0.04 & 0.41 \\
\hline Breeeding-110 d (gain) & $8.23^{\mathrm{b}}$ & $8.60^{\mathrm{ab}}$ & $8.95^{\mathrm{ab}}$ & $9.95^{\mathrm{a}}$ & 0.30 & 0.01 & 0.31 \\
\hline \multicolumn{8}{|c|}{ Estimated protein mass in lactation $(\mathrm{kg})$} \\
\hline $24 \mathrm{~h}$ postpartum & 37.44 & 37.36 & 36.91 & 38.40 & 0.36 & 0.47 & 0.28 \\
\hline $\mathrm{d} 21$ & 38.34 & 38.16 & 37.59 & 36.95 & 0.40 & 0.16 & 0.70 \\
\hline 0-21 d (gain) & $0.90^{\mathrm{b}}$ & $0.80^{\mathrm{b}}$ & $0.67^{\mathrm{b}}$ & $-1.46^{\mathrm{a}}$ & 0.28 & 0.01 & 0.03 \\
\hline Breeeding-21 d (gain) & 6.76 & 6.26 & 5.99 & 5.19 & 0.41 & 0.23 & 0.71 \\
\hline \multicolumn{8}{|c|}{ Estimated fat mass ${ }^{3}$ in gestation $(\mathrm{kg})$} \\
\hline Breeding (d) & 26.94 & 27.98 & 27.16 & 27.71 & 0.82 & 0.88 & 0.94 \\
\hline $110 \mathrm{~d}$ & 39.45 & 40.57 & 40.71 & 43.74 & 1.08 & 0.09 & 0.39 \\
\hline Breeeding-110 d (gain) & 12.51 & 12.59 & 13.56 & 16.03 & 0.80 & 0.03 & 0.26 \\
\hline \multicolumn{8}{|c|}{ Estimated fat mass in lactation $(\mathrm{kg})$} \\
\hline $24 \mathrm{~h}$ postpartum & 36.58 & 35.79 & 35.72 & 38.43 & 0.99 & 0.51 & 0.38 \\
\hline d 21 & 35.75 & 35.32 & 35.21 & 33.40 & 0.97 & 0.44 & 0.73 \\
\hline 0-21 d (gain) & $-0.83^{\mathrm{b}}$ & $-0.47^{\mathrm{b}}$ & $-0.51^{b}$ & $-5.03^{\mathrm{a}}$ & 0.62 & 0.02 & 0.03 \\
\hline Breeding-21 d (gain) & 8.81 & 7.35 & 8.05 & 5.70 & 1.12 & 0.48 & 0.75 \\
\hline
\end{tabular}

SEM, standard error of mean; ME, metabolizable energy.

${ }^{1}$ Energy intake ME kcal/kg.

${ }^{2}$ Prediction equation from Dourmad et al. (1997): $2.28+0.178 \times(\mathrm{EBW}, \mathrm{kg})+0.333 \times($ Backfat, $\mathrm{mm})$.

${ }^{3}$ Prediction equation from Dourmad et al. (1997): $-26.4+0.221 \times(\mathrm{EBW}, \mathrm{kg})+1.331 \times($ Backfat, $\mathrm{mm})$

${ }^{\mathrm{a}, \mathrm{b}}$ Means with different superscripts indicate significant differences $(\mathrm{p}<0.05)$.

energy intake during gestation may increase the risks of nutrition, the body condition, and other management factors. being culled due to pregnancy failure (Kongsted, 2005). These results indicated that dietary energy levels during The pregnancy rate and post-weaning anestrus may be pregnancy for optimal longevity are not easy to establish. correlated with some hormones, and the dietary energy Further study is needed to clearly demonstrate a possible levels differentially affect the release of some reproductive correlation between dietary energy levels during gestation hormones (Kemp et al., 1995). Whitley (2002) reported that and reproductive hormones. WEI is delayed by low plasma insulin targets during reproduction had little connection to insulin concentrations during lactation, and the

Table 4. Effects of the dietary energy level on the reproductive performance and growth of progeny of primiparous sows

\begin{tabular}{|c|c|c|c|c|c|c|c|}
\hline \multirow{2}{*}{ Criteria } & \multicolumn{4}{|c|}{ Treatment } & \multirow{2}{*}{ SEM } & \multicolumn{2}{|c|}{$\mathrm{p}$-value } \\
\hline & $3,100^{1}$ & 3,200 & 3,300 & 3,400 & & Linear & Quadratic \\
\hline \multicolumn{8}{|l|}{ Reproductive performance } \\
\hline Total born & 12.11 & 13.00 & 12.33 & 12.00 & 0.33 & 0.36 & 0.66 \\
\hline Born alive & 11.44 & 12.27 & 11.75 & 11.54 & 0.33 & 0.42 & 0.76 \\
\hline Still birth & 0.67 & 0.73 & 0.58 & 0.46 & 0.08 & 0.61 & 0.56 \\
\hline After cross-fostering & 11.33 & 11.18 & 11.25 & 11.62 & 0.24 & 0.65 & 0.31 \\
\hline Weaning pigs & $11.00^{\mathrm{ab}}$ & $10.27^{\mathrm{b}}$ & $10.58^{\mathrm{ab}}$ & $11.31^{\mathrm{a}}$ & 0.24 & 0.66 & 0.02 \\
\hline \multicolumn{8}{|c|}{ Litter weight on lactation $(\mathrm{kg})$} \\
\hline Litter birth weight & 14.47 & 16.03 & 15.42 & 15.29 & 0.44 & 1.00 & 0.62 \\
\hline After cross-fostering & 14.29 & 14.30 & 14.40 & 14.59 & 0.43 & 0.85 & 0.77 \\
\hline Weaning litter weight & 58.16 & 56.82 & 57.49 & 63.55 & 1.36 & 0.31 & 0.19 \\
\hline \multicolumn{8}{|c|}{ Piglet weight on lactation $(\mathrm{kg})$} \\
\hline Piglet birth weight & 1.19 & 1.25 & 1.25 & 1.30 & 0.03 & 0.23 & 0.96 \\
\hline After cross-fostering & 1.26 & 1.28 & 1.27 & 1.26 & 0.03 & 0.94 & 0.82 \\
\hline Weaning piglet weight & 5.35 & 5.56 & 5.47 & 5.64 & 0.09 & 0.10 & 0.60 \\
\hline
\end{tabular}

SEM, standard error of mean; ME, metabolizable energy.

${ }^{1}$ Energy intake ME kcal/kg.

${ }^{a, b}$ Means with different superscripts indicate significant differences $(p<0.05)$. 
Table 5. Effects of the dietary energy level in gestating sows on the components of colostrum and milk in primiparous lactating sows.

\begin{tabular}{|c|c|c|c|c|c|c|c|}
\hline \multirow{2}{*}{ Items } & \multicolumn{4}{|c|}{ Treatment } & \multirow{2}{*}{ SEM } & \multicolumn{2}{|c|}{ p-value } \\
\hline & $3,100^{1}$ & 3,200 & 3,300 & 3,400 & & Linear & Quadratic \\
\hline \multicolumn{8}{|c|}{ Chemical composition of colostrum at $24 \mathrm{~h}$ postpartum (\%) } \\
\hline Fat & 6.44 & 7.40 & 7.33 & 7.67 & 0.36 & 0.69 & 0.24 \\
\hline Protein & 8.26 & 8.15 & 7.62 & 7.30 & 0.34 & 0.10 & 0.47 \\
\hline Lactose & 4.15 & 4.04 & 4.21 & 4.31 & 0.07 & 0.12 & 0.22 \\
\hline Solids-not-fat & 12.79 & 12.55 & 12.25 & 11.96 & 0.27 & 0.11 & 0.56 \\
\hline \multicolumn{8}{|c|}{ Chemical composition of sow milk at $21 \mathrm{~d}$ postpartum (\%) } \\
\hline Fat & 5.56 & 7.01 & 6.58 & 6.86 & 0.21 & 0.10 & 0.06 \\
\hline Protein & 4.19 & 4.58 & 4.66 & 4.52 & 0.07 & 0.20 & 0.08 \\
\hline Lactose & 6.08 & 5.93 & 5.85 & 5.81 & 0.06 & 0.12 & 0.41 \\
\hline Solids-not-fat & 10.50 & 10.64 & 10.72 & 10.50 & 0.05 & 0.91 & 0.13 \\
\hline
\end{tabular}

SEM, standard error of mean; ME, metabolizable energy.

${ }^{1}$ Energy intake ME kcal $/ \mathrm{kg}$.

concentration is increased by glucose but lowered by FFA concentrations in the plasma of weaning sows (Armstrong et al., 1986). In this study, the plasma glucose and FFA concentrations of sows at weaning were not affected by treatments, indicating that dietary energy levels did not affect WEI.
NRC (2012) suggested dietary energy levels for $140 \mathrm{~kg}$ BW gilts during gestation between $6,678 \mathrm{kcal}$ of $\mathrm{ME} / \mathrm{kg}$ to $7,932 \mathrm{kcal}$ of ME/kg daily. However, our results suggested that litter size was not affected by increasing dietary energy, which may be considered to be a balance between gestation preparation and early gestation. High energy levels had

Table 6. Effects of dietary energy level in gestating sows on the fatty acids composition of colostrum in primiparous lactating sows $(\mathrm{mg} / \mathrm{g})$

\begin{tabular}{|c|c|c|c|c|c|c|c|}
\hline \multirow{2}{*}{ Items } & \multicolumn{4}{|c|}{ Treatment } & \multirow{2}{*}{$\mathrm{SEM}^{2}$} & \multicolumn{2}{|c|}{ p-value } \\
\hline & $3,100^{1}$ & 3,200 & 3,300 & 3,400 & & Linear & Quadratic \\
\hline \multicolumn{8}{|c|}{ Fatty acid composition of colostrum at $24 \mathrm{~h}$ postpartum $(\mathrm{mg} / \mathrm{g})$} \\
\hline \multicolumn{8}{|l|}{ Saturated } \\
\hline Myristic (C14:0) & 0.53 & 0.76 & 0.80 & 0.47 & 0.076 & 0.76 & 0.04 \\
\hline Palmitic (C16:0) & 7.94 & 9.51 & 9.80 & 6.47 & 0.983 & 0.63 & 0.21 \\
\hline Heptadecanioic (C17:0) & 0.16 & 0.18 & 0.17 & 0.13 & 0.014 & 0.44 & 0.35 \\
\hline Stearic $(\mathrm{C} 18: 0)$ & 2.27 & 2.59 & 2.45 & 1.90 & 0.274 & 0.61 & 0.43 \\
\hline Arachidic (C20:0) & 0.06 & 0.07 & 0.06 & 0.05 & 0.007 & 0.57 & 0.38 \\
\hline Henicosanoic (C21:0) & 0.08 & 0.09 & 0.12 & 0.06 & 0.010 & 0.75 & 0.13 \\
\hline Behenic (C22:0) & 0.05 & 0.05 & 0.05 & 0.04 & 0.004 & 0.49 & 0.35 \\
\hline \multicolumn{8}{|l|}{ Monounsaturated } \\
\hline Palmitoleic (C16:1) & 1.19 & 1.77 & 2.24 & 1.17 & 0.218 & 0.80 & 0.05 \\
\hline Nervonic (C24:1) & 0.07 & 0.09 & 0.09 & 0.06 & 0.007 & 0.52 & 0.18 \\
\hline Oleic $(\mathrm{C} 18: \ln 9 \mathrm{c})$ & 13.63 & 16.34 & 18.40 & 12.38 & 1.929 & 0.92 & 0.30 \\
\hline Eicosanoic (C20:1) & 0.13 & 0.16 & 0.16 & 0.11 & 0.021 & 0.78 & 0.37 \\
\hline Erucic (C22:1n9) & 0.03 & 0.04 & 0.03 & 0.03 & 0.004 & 0.78 & 0.48 \\
\hline \multicolumn{8}{|l|}{ Polyunsaturated } \\
\hline Linoleic (C18:2n6c) & 5.88 & 6.73 & 7.52 & 4.64 & 0.681 & 0.63 & 0.19 \\
\hline Cis-11,14-Eicosadienoic (C20:2) & 0.17 & 0.19 & 0.21 & 0.14 & 0.021 & 0.73 & 0.29 \\
\hline$\gamma$-linolenic $(\mathrm{C} 18: 3 \mathrm{n} 6)$ & 0.13 & 0.15 & 0.17 & 0.08 & 0.019 & 0.58 & 0.20 \\
\hline$\alpha$-linolenic (C18:3n3) & 0.27 & 0.32 & 0.38 & 0.23 & 0.033 & 0.87 & 0.15 \\
\hline Arachidonic (C20:4n6) & 0.40 & 0.37 & 0.51 & 0.29 & 0.046 & 0.67 & 0.36 \\
\hline Cis-11,14,17-Eicosatrienoic (C20:3n3) & 0.03 & 0.03 & 0.04 & 0.03 & 0.004 & 0.99 & 0.31 \\
\hline $\begin{array}{l}\text { Cis-5,8,11,14,17Ecicosapentaenoic } \\
\text { (C20:5n3) }\end{array}$ & 0.03 & 0.03 & 0.04 & 0.02 & 0.003 & 0.99 & 0.29 \\
\hline $\begin{array}{l}\text { Cis-4,7,10,13,16,19-Docosahexaenoic } \\
\quad(\mathrm{C} 22: 6 \mathrm{n} 3)\end{array}$ & 0.02 & 0.02 & 0.03 & 0.02 & 0.003 & 0.86 & 0.55 \\
\hline
\end{tabular}

SEM, standard error of mean; ME, metabolizable energy.

${ }^{1}$ Energy intake ME kcal/kg. 
Table 7. Effects of the dietary energy level on the BUN, glucose and free fatty acid concentrations in the plasma of primiparous sows

\begin{tabular}{|c|c|c|c|c|c|c|c|}
\hline \multirow{2}{*}{ Criteria } & \multicolumn{4}{|c|}{ Treatment } & \multirow{2}{*}{ SEM } & \multicolumn{2}{|c|}{ p-value } \\
\hline & $3,100^{1}$ & 3,200 & 3,300 & 3,400 & & Linear & Quadratic \\
\hline \multicolumn{8}{|l|}{ BUN (mg/dL) } \\
\hline Breeding (d) & 10.60 & 10.60 & 10.60 & 10.60 & & & \\
\hline $110 \mathrm{~d}$ & 9.06 & 8.72 & 7.08 & 7.82 & 0.37 & 0.07 & 0.39 \\
\hline $24 \mathrm{~h}$ postpartum & 11.68 & 10.48 & 9.06 & 9.50 & 0.59 & 0.06 & 0.36 \\
\hline Weaning & 20.76 & 19.70 & 17.12 & 18.68 & 0.83 & 0.24 & 0.44 \\
\hline \multicolumn{8}{|l|}{ Glucose (mg/dL) } \\
\hline Breeding (d) & 76.20 & 76.20 & 76.20 & 76.20 & & & \\
\hline $110 \mathrm{~d}$ & 74.00 & 81.60 & 69.80 & 73.00 & 2.56 & 0.39 & 0.57 \\
\hline $24 \mathrm{~h}$ postpartum & 87.50 & 88.40 & 89.25 & 95.20 & 1.77 & 0.07 & 0.37 \\
\hline Weaning & 82.50 & 82.00 & 81.40 & 82.80 & 3.37 & 0.99 & 0.90 \\
\hline \multicolumn{8}{|c|}{ Free fatty acid $(\mu \mathrm{Eq} / \mathrm{L})$} \\
\hline Breeding (d) & 140.60 & 140.60 & 140.60 & 140.60 & & & \\
\hline $110 \mathrm{~d}$ & 145.20 & 146.00 & 189.40 & 183.20 & 12.10 & 0.22 & 0.90 \\
\hline $24 \mathrm{~h}$ postpartum & 257.60 & 211.00 & 232.20 & 292.60 & 21.03 & 0.56 & 0.27 \\
\hline Weaning & 182.20 & 158.00 & 171.40 & 170.20 & 12.81 & 0.86 & 0.69 \\
\hline
\end{tabular}

BUN, blood urea nitrogen; SEM, standard error of mean; ME, metabolizable energy.

${ }^{1}$ Energy intake ME kcal $/ \mathrm{kg}$.

positive effects on the ovulatory rate, but high energy levels might decrease embryonic survival after breeding (Jindal et al., 1996), while low energy supplies from day 3 after mating until day 15 do not affect embryo survival.

There are many of scientific studies assessing the effects of increased feed or energy intake in gestating sows on piglet birth weight (NRC, 1998). Daily energy requirements during gestation include maintenance for the sow maternal gain as well as uterine growth. Increased energy intake during late gestation can positively affect fetal growth (NRC, 2012). In this experiment, there was no treatment effect on litter birth weight and individual piglet birth weight, which is consistent with the results from Long (2010), who demonstrated that the average piglet BW at farrowing was not affected by energy levels in gestation diets. Increased feed intake during gestation also did not increase the litter weight or individual piglet weight (Piao et al., 2010). This result demonstrates that increased feed intake during gestation could increase BW gain and BFT in gestating gilts. However, increased BW and backfat did not increase litter weight or individual piglet weight.

Yang (2008) reported that there was no change in colostrum composition when the energy levels increased from 13.7 to $14.2 \mathrm{MJ}$ of ME/kg during gestation. Our study suggests that there were no significant differences in the chemical composition (fat, protein, lactose and SNF) of sow colostrum and milk, which is consistent with the results from Willams (1985), who confirmed that the chemical composition of colostrum and milk was not affected by dietary energy levels during gestation because sows mobilized their internal reserves to compensate for deficient nutrients. In the present study, the composition of fatty acids in colostrum did not show any changes due to the dietary energy level of the gestation diets. The fatty acid composition of colostrum is affected by dietary fat levels (Christon et al., 1999). Several studies have investigated how the composition of fatty acids in colostrum is affected by energy levels in gestation diets, and the mechanism is not yet clearly understood. In this experiment, the composition of fatty acids did not show any changes due to the different treatments, but the differences in energy levels among treatments simply may not have been high enough to affect the composition of fatty acids in colostrum.

It is well known that BUN is directly related to protein intake and inversely related to protein quality (Hahn et al., 1995) and the retention of dietary nitrogen in the body (Whang and Easter, 2000). In the present study, the BUN concentration in serum tended to decrease with the increasing energy level at 110 days of gestation and 24 hours post-farrowing. Ruiz (1971) reported that the BUN

Table 8. Effects of the dietary energy level in gestating sows on immune parameters of colostrum ${ }^{1}$ in primiparous lactating sows

\begin{tabular}{|c|c|c|c|c|c|c|c|}
\hline \multirow{2}{*}{ Items } & \multicolumn{4}{|c|}{ Treatment } & \multirow{2}{*}{ SEM } & \multicolumn{2}{|c|}{$\mathrm{p}$-value } \\
\hline & $3,100^{2}$ & 3,200 & 3,300 & 3,400 & & Linear & Quadratic \\
\hline $\mathrm{IgG}(\mathrm{mg} / \mathrm{mL})$ & 5.44 & 5.58 & 5.36 & 4.95 & 0.60 & 0.81 & 0.86 \\
\hline $\operatorname{IgA}(\mathrm{mg} / \mathrm{mL})$ & 5.58 & 4.03 & 5.46 & 5.25 & 0.67 & 0.94 & 0.58 \\
\hline
\end{tabular}

SEM, standard error of mean; ME, metabolizable energy.

${ }^{1} 24$ hours postpartum. ${ }^{2}$ Energy intake ME kcal $/ \mathrm{kg}$. 
concentration was higher in swine fed low-energy diets compared to pigs fed high-energy diets, which may suggest that energy intake in sows is affected by protein metabolism during gestation. The glucose concentration influences insulin secretion (Quesnel and Prunier, 1998), and insulin can reduce the oxidation of FFA for the production of energy (Gamble and Cook, 1985). The glucose concentration increased with higher energy levels 24 hours post-farrowing in the current study, whereas FFAs were not affected by treatments. Xue (1997) demonstrated that increased energy levels during gestation could decrease glucose utilization and subsequently decrease feed intake during lactation. Piao (2010) also suggested that increased feed intake in gestating gilts may cause sows to become insensitive to insulin, thereby exhibiting a smaller response in glucose clearance and decreased feed intake during lactation. Therefore, it can be assumed that the effect of insulin on feed intake in lactation might depend on the body condition of sows and metabolites of glucose, which may explain our result that BW and BFT decreased with energy levels during lactation.

A greater intake of immunoglobulins in colostrum may increase immune function in nursing pigs. Some previous research reported that polyunsaturated fatty acids (PUFA) can influence production of immunoglobulins in mammals. Mitre et al. (2005) reported that supply of shark-liver oil to sows from d 80 of gestation to farrowing could be increased $\operatorname{IgG}$ concentrations in the colostrum, but not IgA. Mateo et al. (2009) reported increased $\operatorname{IgG}$ concentrations in the colostrum and milk of sows fed a fish product. Clearly, dietary n-3 and n-6 FA's are involved in immune and inflammatory processes.

In the present study, the concentrations $\operatorname{IgG}$ and $\operatorname{IgA}$ in colostrum was not affected by the tallow in gilt diets, which has lower PUFA than other energy source.

\section{IMPLICATIONS}

NRC (2012) suggested that the energy requirement of the gestation gilt should be between 6,678 and $7,932 \mathrm{kcal}$ of $\mathrm{ME} / \mathrm{d}$. Similarly, our results suggested that $3,100 \mathrm{kcal}$ of $\mathrm{ME} / \mathrm{kg}$ is not enough to maintain the reproductive performance for gilts during gestation with $2 \mathrm{~kg}$ feed daily. Gilts in the treatment $3,400 \mathrm{kcal}$ of $\mathrm{ME} / \mathrm{kg}$ tended to have a higher weaning number of piglets, but bodyweight and backfat loss were higher than other treatments during lactation. Consequently, an adequate energy requirement of gestating gilts is $6,400 \mathrm{kcal}$ of $\mathrm{ME} / \mathrm{d}$.

\section{CONFLICT OF INTEREST}

We certify that there is no conflict of interest with any financial organization regarding the material discussed in the manuscript.

\section{ACKNOWLEDGMENTS}

This work was carried out with the support of "Cooperative Research Program for Agriculture Science and Technology Development (Project No. PJ009226012013)" Rural Development Administration, Republic of Korea.

\section{REFERENCES}

Almeida, F. R. C. L., R. N. Kirkwood, F. X. Aherne, and G. R. Foxcroft. 2000. Consequences of different patterns of feed intake during estrous cycle in gilts on subsequent fertility. J. Anim. Sci. 78:1566-1563.

AOAC. 1990. Official Methods of Analysis. 15th ed. National Research Council, Association of Official Analytical Chemists, Arlington, VA, USA.

Armstrong, J. D., J. H. Britt, and R. R. Kraeling. 1986. Effect of restriction of energy during lactation on body condition, energy metabolism, endocrine changes and reproductive performance in primiparous sows. J. Anim. Sci. 63:1915-1925.

Baidoo, S. K., F. X. Aherne, R. N. Kirkwood, and G. R. Foxcroft. 1992. Effect of feed intake during lactation and after weaning on sow reproductive performance. Can. J. Anim. Sci. 72:911917.

Boyd, R. D., K. J. Touchette, G. C. Castro, M. E. Johnston, K. U. Lee, and In K. Han. 2000. Recent advances in amino acid and energy nutrition of prolific sows. Asian Australas. J. Anim. Sci. 13:1638-1652.

Christon, R., G. Saminadin, H. Lionet, and B. Racon. 1999. Dietary fat and climate alter food intake, performance of lactating sows and their litters and fatty acid composition of milk. Anim. Sci. 69:353-365.

Dourmad, J. Y., M. Etienne, J. Noblet, and D. Causeur. 1997. Prediction of the chemical composition of the reproductive sows from their bodyweight and backfat depth- Utilization for determining the energy rcordance. J. Rech. Porc. France. 29:255-262.

Gamble, M. S. and G. A. Cook. 1985. Alteration of the apparent $\mathrm{Ki}$ of carnitine palmitoyltransferase for malonyl-CoA by the diabetic state and reversal by insulin. J. Biol. Chem. 260:95169519.

Hahn, J. D., R. R. Biehl, and D. H. Baker. 1995. Ideal digestible lysine for early- and late-finishing swine. J. Anim. Sci. 73:773784

Jang, Y. D., S. K. Jang, D. H. Kim, H. K. Oh, and Y. Y. Kim. 2014. Effects of dietary protein levels for gestating gilts on reproductive performance, blood metabolites and milk composition. Asian Australas. J. Anim. Sci. 27:83-92.

Jindal, R., J. R. Cosgrove, F. X. Aherne, and G. R. Foxcroft. 1996. Effect of nutrition on embryonal mortality in gilts: Association with progesterone. J. Anim. Sci. 74:620-624.

Kemp, B., N. M. Soede, F. A. Helmond, and M. W. Bosch. 1995. Effects of energy source in the diet on reproductive hormones and insulin during lactation and subsequent estrus in 
multiparous sows. J. Anim. Sci. 73:3022-3029.

Kongsted, A. G. 2005. A review of the effect of energy intake on pregnancy rate and litter size-discussed in relation to grouphoused non-lactating sows. Livest. Prod. Sci. 97:13-26.

Kirkwood, R. N. and P. A. Thacker. 1988. Nutritional factors affecting embryonic mortality in pigs. Pig News Info. 9:15-21.

Long, H. F., W. S. Ju, L. G. Piao, and Y. Y. Kim. 2010. Effect of dietary energy levels of gestating sows on physiological parameters and reproductive performance. Asian Australas. J. Anim. Sci. 23:1080-1088.

Mitre, R., M. Etienne, S. Martinais, H. Salmon, P. Allaume, P. Legrand, and A. B. Legrand. 2005. Humoral defence improvement and haematopoiesis stimulation in sows and offspring by oral supply of shark-liver oil to mothers during gestation and lactation. Br. J. Nutr. 94:753-762.

Mateo, R. D., J. A. Carroll, Y. Hyun, S. Smith, and S. W. Kim. 2009. Effect of dietary supplementation of n-3 fatty acids and elevated concentrations of dietary protein on the performance of sows. J. Anim. Sci. 87:948-959.

Noblet, J., J. Y. Dourmad, and M. Etienne. 1990. Energy utilization in pregnant and lactating sows: Modeling of energy requirements. J. Anim. Sci. 68:562-572.

NRC. 1998. Nutrient Requirements of Swine, 10th ed. Natl. Acad. Press, Washington, DC, USA.

NRC. 2012. Nutrient Requirements of Swine, 11th ed. Natl. Acad. Press, Washington, DC, USA.

Piao, L. G., W. S. Ju, H. F. Long, and Y. Y. Kim. 2010. Effects of various feeding methods for gestating gilts on reproductive performance and growth of their progeny. Asian Australas. J. Anim. Sci. 23:1354-1363.
Quesnel, H. and A. Prunier. 1998. Effect of insulin administration before weaning on reproductive performance in feed restricted primiparous sows. Anim. Reprod. Sci. 51:119-129.

Ruiz, M. E., R. C. Ewan, and V. C. Speer. 1971. Serum metabolites of pregnant and hysterectomized gilts fed two levels of energy. J. Anim. Sci. 32:1153-1159.

SAS Institute Inc. 2004. SAS/STAT User's Guide, SAS Institute Inc., Cary, NC, USA.

Shimizu, S., K. Inoue, Y. Tani, and H. Yamada. 1979. Enzymatic microdetermination of serum free fatty acids. Analytical biochemistry. 98:341-345.

Whang, K. Y. and R. A. Easter. 2000. Blood urea nitrogen as an index of feed efficiency and lean growth potential in growing finishing-swine. Asian Australas. J. Anim. Sci. 13:811-816.

Whitley, N. C., M. Thomas, J. L. Ramirez, A. B. Moore, and N. M. Cox. 2002. Influences of parity and level of feed intake on reproductive response to insulin administration after weaning in sows. J. Anim. Sci. 80:1038-1043.

Williams, I. H., W. H. Close, and D. J. A. Cole. 1985. Strategies for sow nutrition: Predicting the response of pregnant animals to protein and energy intake. In: Recent Advances in Animal Nutrition (Eds. W. Haresign and D. J. A. Cole). Butterworth, London, UK. pp. 133-147.

Xue, J. L., Y. Koketsu, G. D. Dial, J. E. Pettigrew, and A. Sower. 1997. Glucose tolerance, luteinizing hormone release, and reproductive performance of first-litter sows fed two levels of energy during gestation. J. Anim. Sci. 75:1845-1852.

Yang, Y., S. Heo, Z. Jin, J. Yun, P. Shinde, J. Choi, B. Yan, and B. Chae. 2008. Effects of dietary energy and lysine intake during late gestation and lactation on blood metabolites, hormones, milk composition and reproductive performance in multiparous sows. Arch. Anim. Nutr. 62:10-21. 